\title{
Original
}

\section{Molecular cloning of sucrose-hydrolyzing enzyme genes from Streptococcus mutans in bacteriophage lambda L 47}

\author{
バクテリオファージラムダ L 47を用いた Streptococcus mutans \\ スクロース分解醳素の遺伝子クローニング \\ Yukie SHIBATA*, Yoshihisa YAMASHITA*, \\ Nobuhiro HANADA* and Tadamichi TAKEHARA*

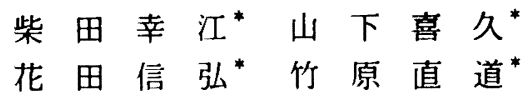

Received July 18, 1989 ; accepted August 31, 1989

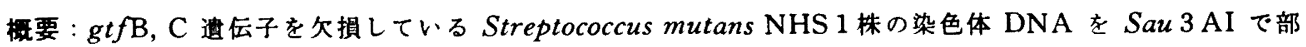
分切断した後, Bam HI で切断したバクテリオフォージラムダ L47ベクターにつないだ。in vitro パッヶージ ング後，ラムダファージを指示菌の大腸菌 C600P 2 に感染させたファージクローンバンクを作慗した。スク ロースを唯一の炭素源とする M 9 培地上では大晹菌が生育できない事を利用してクローンバンクからスクロ

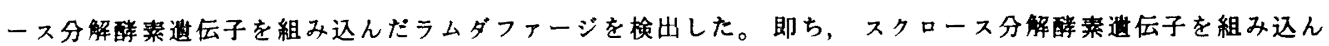
だラムダファージのプラーク周囲ではスクロースが分解し，グルコースとフルクトースが生じる。このため 大渴菌の生育が良くなりプラークの周囲に輸が锳察されるようになる。この方法で13クローンが選択され た。このうち5クローンには強いインベルターゼ活性が認められた。更にそのうちの1つのクローンにはグ ルコシル基の転移活性が認められたが，グルカン合成活性はなかった。
\end{abstract}

Koy words: Recombinant DNA technique, Bacteriophage lambda, Sugar metabolism, Streptococcus mutans

索引用語：組み換え DNA 技術, バクテリオファージ ラムタ, 糖代媩, ストレプトコッカスミュータンス

\section{Introduction}

Streptococcus mutans has been recognized as the principal causative bacterium of human dental caries $^{1}$. This organism possesses a variety of pathways for metabolizing dietary sucrose. These pathways are believed to be an important factor in the ability of $S$. mutans to cause dental caries. The conversion of dietary sucrose to glucan is the most important cariogenic property of $S$. mutans. This organism also uses dietary sucrose as a source of carbon and energy. The enzymes involved in metabolism of sucrose,

* Department of Preventive Dentistry, Kyushu Dental College (Director: Prof. Tadamichi TAKEHARA)

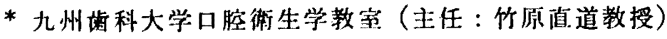


both intra- and extracellularly, are greatly complicated. Recombinant DNA techniques are suitable for the analysis of such complex situations because the genes responsible for individual functions can be isolated. Such genes can be cloned into a novel genetic circumstance. Recently, the three glucosyltransferase genes $(g t f)$ of $S$. mutans were cloned ${ }^{2-4}$. These genes are important for dental caries. In order to get more progressive information about dental caries, we need to find all sucrose-hydrolyzing enzyme (invertase) genes in $S$. mutans. In this paper we described the application of a bacteriophage vector system for the molecular cloning of several sucrose-hydrolyzing enzyme genes from $S$. mutans.

\section{Materials and Methods}

1. Bacterial strains

Escherichia coli $\mathrm{C} 600$ and $\mathrm{C} 600$ (P2) were kindly provided by Howard K. Kuramitsu, Northwestern University, Chicago, Illinois. S. mutans strain NHS1, which lacks most of the gtfB and $\mathrm{C}$ genes, was described previously3). Lambda L47 DNA was obtained from Amersham Japan Corp., Tokyo. E. coli strains were grown in L broth ( $10 \mathrm{~g}$ of tryptone [Difco Laboratories, Detroit, Mich.], $5 \mathrm{~g}$ of yeast extract [Difco], $5 \mathrm{~g}$ of $\mathrm{NaCl}$ per liter). Phage stocks were prepared on LB agar plates in the top agar overlays ${ }^{5}$.

\section{DNA manipulations}

Chromosomal DNA from $S$. mutans NHS1 was purified essentially as previously described ${ }^{6}$, extracted with phenol, phenol/chloroform and chloroform, precipitated with ethanol (2x), and dissolved in TE buffer (10 mM Tris hydrochloride, $1.0 \mathrm{mM}$ EDTA $[\mathrm{pH} \mathrm{8.0]).} \mathrm{These} \mathrm{cycles} \mathrm{were} \mathrm{repeated} \mathrm{ten} \mathrm{times.}$

3. Construction of the $S$. mutans clone bank

Chromosomal DNA from $S$. mutans NHS1 was partially digested with restriction endonuclease enzyme Sau3AI. DNA fragments of over $6 \mathrm{~kb}$ were isolated from an agarose gel. These fragments were mixed with lambda L47 DNA which was completely digested with BamHI in a 1:1 ratio (total DNA concentration was $300 \mu \mathrm{g} / \mathrm{m} l)$. DNA fragments were ligated at $12^{\circ} \mathrm{C}$ for $16 \mathrm{~h}$ in the presence of T4 DNA ligase. After ligation, the mixture was phenol extracted, phenol/chloroform extracted, chloroform extract. ed and ethanol precipitated (2x). The ligation mixture was dissolved in $11 \mu l \mathrm{TE}$ buffer. In vitro packaging of the ligation mixture $(5 \mu l)$ was done with a packaging kit following the directions of the supplier (Amersham Japan). E. coli $\mathrm{C} 600$ (P2) cells were infected with the packaging mixture for $20 \mathrm{~min}$ at $37^{\circ} \mathrm{C}$ in $10 \mathrm{mM} \mathrm{MgSO}$. Infected E. coli were mixed with $3.0 \mathrm{ml}$ of LB top agar and plated on LB agar plates at $37^{\circ} \mathrm{C}$ for 8 to $16 \mathrm{~h}$. The resultant plaques were harvested by scrubbing each plate with $3.0 \mathrm{ml}$ of lam. bda dilution buffer $(10 \mathrm{mM}$ Tris, $10 \mathrm{mM} \mathrm{MgSO} 4[\mathrm{pH} 7.5])$. The clone bank was stored at $4^{\circ} \mathrm{C}$ and was used to infect $\mathrm{C} 600$ cells for subsequent screening.

4. Screening of clone bank

The recombinant phage clone bank was plated with E. coli $\mathrm{C} 600$ in soft agar made with LB on top of M9 minimal salts agar medium $\left(6 \mathrm{~g}\right.$ of $\mathrm{Na}_{2} \mathrm{HPO}_{4}, 3 \mathrm{~g}$ of $\mathrm{KH}_{2} \mathrm{PO}_{4}, 0.5 \mathrm{~g}$ of $\mathrm{NaCl}, 1 \mathrm{~g}$ of $\mathrm{NH}_{4} \mathrm{Cl}$ and $15 \mathrm{~g}$ of agar per liter) containing $0.4 \%$ sucrose as the only carbon source and supplements $(1 \mu \mathrm{g} / \mathrm{m} l$ of thiamine hydrochloride, $8 \mu \mathrm{g} / \mathrm{ml}$ of L-leucine and $8 \mu \mathrm{g} / \mathrm{ml}$ of L-threonine) required by $E$. coli C600. Plates were incubated 2 or 3 days at $37^{\circ} \mathrm{C}$. Recombinant plaques suspected of containing sucrose-hydrolyzing enzyme genes were picked and checked for their invertase activity.

5. Enzyme assays

Invertase activity was determined as previously described ${ }^{7}$ in a standard incubation mixture containing $100 \mathrm{mM}$ potassium phosphate buffer $(\mathrm{pH} 6.0), 2 \%$ sucrose, $0.2 \%$ saline- $\mathrm{NaN}_{\mathrm{s}}$, enzyme, and water in a total volume of $0.1 \mathrm{~m} l$. The reaction mixtures were incubated for $30 \mathrm{~min}$ at $37^{\circ} \mathrm{C}$ and analyzed for reduc- 
a b c

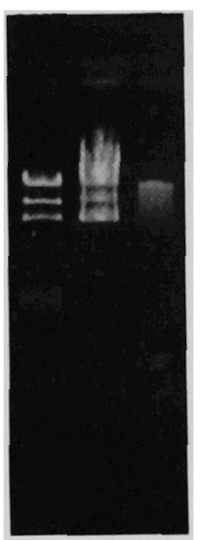

Fig. 1 Restriction enzyme digestion profiles. (a) Molecular size marker, lambda DNA Hind III fragments (23, 9.4, $6.6,4.4,2.3$ and $2.0 \mathrm{~kb}$ ), (b) Lambda phageL47 DNA BamHI digestion, (c) S. mutans NHSl chromosomal DNA Sau 3AI partial digestion.

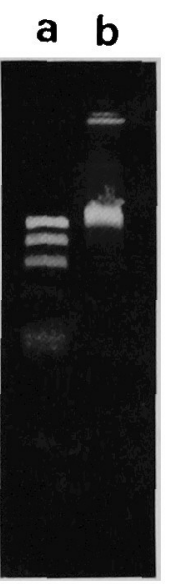

Fig. 2 Ligation profile of the S. mutans clone bank. (a) Lambda DNA HindIII fragments, (b) After ligation of $S$. mutans NHSl chromosomal DNA and lambda phage DNA utilizing T4 ligase.

ing sugar formation by the Somogyi-Nelson procedure. The difference of the amounts of free glucose and fructose in the reaction mixture was determined by the F-kit (Boehringer Mannheim, FRG), a biochemical assay of fructose/glucose $e^{8)}$.

\section{Results}

1. Construction of clone bank

Fig. 1 shows the digestion profiles of the $S$. mutans chromosamal DNA and lambda phage L47 DNA. Fig. 2 shows the ligation profile of the $S$. mutans lambda phage clone bank. The DNA concentration and the purity of DNA fragments were important factors during the ligation and in vitro packag. ing procedures.

2. Detection of sucrose-hydrolyzing enzyme recombinants

The phage detection method depends on the fact that $E$. coli $\mathrm{K} 12$ is unable to transport sucrose into the cell. But $E$. coli fermented monosaccharides (glucose or fructose). In this experiment monosaccharides were produced by cleavage of sucrose which existed in the bottom agar. Monosaccharides in the top agar layer allowed a faint lawn of $E$. coli to grow, sufficient to support phage multiplication and form. ation of plaques. The production of monosaccharides in plaques where sucrose-hydrolyzing enzyme genes were expressed supported much more growth and plaques were surrounded by haloes of $E$. coli.

Thirteen of a total of 2000 plaques from the lambda phage clone bank showed such haloes.

3. Enzyme activity of the recombinants

The invertase activity of 13 phage clone lysates prepared from cross-feeding recombinants was examined by Somogyi-Nelson procedures. Strong invertase activity was detected from 5 clones. Weak activities were detected from 4 clones. In spite of the existence of haloes, we could not detect any invertase activity in the remaining 4 clones. The amount of free glucose and fructose in the reaction mixture was 
determined by the F-kit (Table 1). Fructose/ glucose ratio showed that clones No. 1 to No. 4 had no detectable glucosyl residue transfer activity. Clone No. 7 showed glucosyltransferase-like activity. But no glucan formation activity was detected at this time (data not shown).

\section{Discussion}

The data presented in this communication demonstrate that the sequence encoding the sucrose-hydrolyzing enzyme genes of $S$. mutans has been cloned in $E$. coli on a Lambda L47 replacement vector.

We expected to have glucan forming activity from phage lysates. But we could not find such plaques with this cloning method. Clone No. 7 probably had transfer activity of glucosyl residue. However, we could not get any glucan forming activity from No. 7 clone. We intend to characterize clone No. 7 in future.

A screening procedure similar to that described here was earlier used by Franklin ${ }^{9}$ to detect lambda $\operatorname{trp}$ recombinants, by Gilpin et al..$^{103}$ in studies of $g t f$ genes and by Russell et al.11) in studies of scr and $g t f \mathrm{~A}$ genes. E. coli $\mathrm{K} 12$ is normally unable to transport sucrose into the cell so that cloning systems based upon plasmid vectors require the devising of different methods for uptake of the sugar ${ }^{12}$. The advantage of the lambda system is that sucrose-hydrolyzing enzymes from $S$. mutans carried by recombinant phage are produced and released to the outside of the $E$. coli cells. This is why we can detect their activity within the resultant plaques.

The characterization of these sucrose-hydrolyzing enzymes and analysis of the complex pathways of sugar metabolism will be greatly helped by the development of recombinant DNA techniques for cloning and expression of Streptococcus mutans genes in E. coli.

\section{Acknowledgement}

This study was supported in part by a Grant (1989) 01870090, in aid for Basic Scientific Research, from the Education Ministry, Japan.

\section{References}

1) Loesche, W. J. : Role of Streptococcus mutans in human dental decay. Microbiol. Rev., 50 ; 353, 1986.

2) Aoki, H., Shiroza, T., Hayakawa, M., Sato, S. and Kuramitsu, H. K.: Cloning of a Streptococcus mutans gene coding for insoluble glucan synthesis. Infect. Immun., 53 ; 587, 1986.

3) Hanada, N. and Kuramitsu, H. K.: Isolation and characterization of the Streptococcus mutans gtfC gene, coding for synthesis of both soluble and insoluble glucans. Infect. Immun., 56 ; 1999, 1988.

4) Hanada, N. and Kuramitsu, H. K. : Isolation and characterization of the Streptococcus mutans gtf $\mathrm{D}$ gene coding for primer-dependent soluble glucan synthesis. Infect. Immun., 57 ; 2079, 1989.

5) Maniatis, T., Fritsch, E. F. and Sambrook, J. : Molecular cloning : a laboratory manual. Cold Spring Harbor Laboratory, Cold Spring Harbor, 1982. 
6) Jagusztyn-Krynicka, E. K., Smorawinska, M. and Curtiss, R. III : Expression of Streptoco. ccus mutans aspartate-semialdehyde dehydrogenase gene cloned into plasmid pBR322. J. Gen. Microbiol., 128 ; 1135, 1982.

7) Maynard, M. T. and Kuramitsu, H. K. : Purification and antigenic properties of intracellular invertase from Streptococcus mutans. Infect. Immun., $23 ; 873,1979$.

8) Yamashita, Y., Hanada, N., Itoh-Andoh, M. and Takehara, T.: Evidence for the presence of two distinct sites of sucrose hydrolysis and glucosyl transfer activities on 1,3- $\alpha \cdot \mathrm{D}$. glucan synthase of Streptococcus mutans. FEBS Lett. 243 ; 343, 1989.

9) Franklin, N. C. : in The Bacteriophage Lam- bda (Ed. by Hershey, A. D.), Cold Spring Harbor Laboratory, Cold Spring Harbor, 1971, p. 621.

10) Gilpin, M. L., Russell, R. R. B. and Morrissey, P.: Cloning and expression of two $S t$. reptococcus mutans glucosyltransferases in Escherichia coli K-12. Infect. Immun., 49 ; 414, 1985.

11) Russell, R. R. B., Morrissey, P. and Dougan, G. : Cloning of sucrase genes from Str. eptococcus mutans in bacteriophage lambda. FFMS Microbiol. Lett., 30 ; 37, 1985.

12) Robeson, J. P., Barletta, R. G. and Curtiss, R. III : Expression of a Streptococcus mutans glucosyltransferase gene in Escherichia coli. J. Bacteriol., $153 ; 211,1983$. 